\title{
Renewal and Revivalism in Ghanaian Methodism: The Catalytic Role of Prayer Fellowships
}

\author{
Samuel B. Adubofuor ${ }^{1}$ (iD) \& Hosea Osei ${ }^{2}$ \\ ${ }^{1}$ Department of Theology, Christian Service University College, Kumasi, Ghana. \\ ${ }^{2}$ Methodist Church, Ghana.
}

\begin{abstract}
Branded prayer programmes have taken centre stage in contemporary Ghanaian Christianity, and Methodism in Ghana has its fair share. The origins of these spiritual activities are nebulous. This study investigates the historical roots of the contemporary revival and renewal programmes in Methodist Church Ghana. Through historical and phenomenological research approach, the study highlights the catalytic role played by the twentieth-century prayer fellowships, which functioned as fringe groups in the Church. A re-visioning of John Wesley as a Pentecostal fore-bearer of the Christian faith constitutes an innovative attempt at situating the charismatic renewal movement in Ghana within historic Methodism. The study evinces the critical function of the laity as agents of revival and renewal of spirituality in the Church. Essentially, through the prayer fellowships, the ministry of the Methodist Church is democratised, and clericalism neutralised. The transformation of the prayer fellowship movement into the Methodist Prayer and Renewal Programme (M.P.R.P.) facilitated the formalisation, institutionalisation and regulation of the emergent charismatic movement into a "Connexional" (i.e. nationwide) Methodist activity. What makes the M.P.R.P. relevant is its dynamic response to the African worldview and existential realities of the participants.
\end{abstract}

Keywords: Prayer Fellowships, Methodist Church, Renewal, Programmes, Pentecostal

\section{Correspondence:}

Samuel B. Adubofour

Email: sadubofour@csuc.edu.gh

Publication History

Received 30th September 2020,

Accepted 2nd November 2020,

Published online 16th

November 2020.

\section{INTRODUCTION}

In Ghana today, there are various spiritual renewal programmes organized by church and parachurch groups which by and large energize Christianity in the country by giving it a fresh lease of life. Worship in the Methodist Church Ghana (M.C.G.) has gone through many phases. Before becoming an autonomous church, the Methodist Church Ghana contented itself with the liturgy of the British Methodist Church. The attachment to the apron strings of the parent Church however changed with time, especially with the advocacy for selfhood and relevance from the 1960s onwards. Currently, the M.C.G. is clad with many renewal programmes, primarily to retain its membership and also attract new members. The programmes include the Methodist Prayer and Renewal Programme (M.P.R.P.), Mpaebo Kesee (The Great Prayer), Good Morning Holy Spirit, PUSH (Pray Until Something Happens), Ntentam (Wrestling), Hour of Visitation, Kairos Moment, Morning Dew, Prophetic Convention, and Diocesan All-Night Prayer Meeting, with the epicenter being Kumasi. However, not much is known of the Methodist Prayer Fellowship movement which emerged in the 1980s, flourished into the 1990s, and established the foundations for the charismatic renewal activities in the Church today. This study thus seeks to provide an annotated historical account of the origins of the Prayer Fellowship movement in the Methodist Church Ghana and its transformation and consolidation into the Methodist Prayer and Renewal Programme.

\section{Concept of Spiritual Renewal}

The usage of the word "renew" occurs in several passages of the Bible. There is a renewal which implies regaining of inner strength, resulting in the pursuit for God (Isa. 40:31; 41:1; Lam. 5:21; 2 Cor. 4:16). In other contexts, there is a 
stress on the acquisition of knowledge as a means of providing mental renewal (Rom. 12:12; Eph. 4:23; Col. 3:10). This mental alignment to God's truth is the foundation of value clarification which the believer begins to pursue at conversion (Rom. 12:2). Some writers view renewal from the perspective of repentance (Psalm 51:10; Heb. 6:6).

In this research, the expression' spiritual renewal' is used synonymously with the cognate expression 'revival', in endeavoring to articulate the import of innovations occurring within Ghanaian Christianity. Renewal presupposes articulating a response to flagging zeal and spirituality. Spiritual renewal makes room for spontaneity in both the individual and the corporate church. Renewal connotes not just a restoration of the individual to God from nominal Christianity. According to Asamoah-Gyadu, spiritual renewal is "a response to that which has now become static, staid, institutionalized, legalistic, bureaucratized, formalized, and routinized in the religious and spiritual life of the individual and of the church." Renewal is thus a response to a perceived loss of a church's of life and vitality leading to a stagnation of her growth and mission.

Another concept that is closely related to revitalization and restoration is revival. It is an older term that tends to focus on the spiritual renewal of the church. At the conceptual level, these terms are similar or synonymous. They are used alternatively to imply the church is in decline or decay in one way or the other and that action must be taken to make the church flourish once again. According to Carson, "Protestants describe the continuous needed restoring and refreshing of the church, with the word revival denoting an altogether supernatural visitation of the Church of God bringing conviction, repentance, and recovery of backsliders."

According to Buttler, "council speakers of St. Cyprian explain the concept of renewal to mean back to Christ." To him, the founders of religious orders were stirred up by the Holy Spirit for the building up of the church, so also was Christ. Therefore "back to Christ" means back to the Spirit and special purposes of Christ. Battley observes, "The twentyfirst-century church has been characterized by a whole series of renewal movements, each focusing on a particular aspect of ecclesiastical life." 4 He contends that the surge in renewal movements has not found much meaning and expression within the ecclesia. He further asserts that the results of these renewal movements have been unhealthily fragmented hence what is needed is a holistic or integrated vision of renewal in every dimension of the church's life. ${ }^{5}$ Bittlinger thinks "spiritual renewal must be understood in terms of a response to the orderly and overly rational approach to the phenomenon."

Warner describes the controversial and electrifying events taking place in churches around the world. $\mathrm{He}$ explains the strong emotional and physical responses by examining biblical accounts of what happens when people encounter God in power."' He compares current events with previous periods of renewal. He again warns against some common dangers and reveals the vital signs of a genuine wave of the Holy Spirit. Warner in his assertion cautions the church to be careful not to introduce certain doctrines outside the beliefs of the church when accepting the renewal phenomenon.

Stott cautions "the church not to separate what God has joined. Instead, every churchman and woman must seek the renewal of the church in all four dimensions of truth, holiness, mission, and unity." ${ }^{\prime}$ This will help the church to faithfully guard the revelation which was once entrusted to it. He concludes that these goals would be accomplished if the present church goes through renewal. The description given by Stott is not different from the kind of renewal which the Ghanaian Christian community is experiencing, which is the supernatural visitation of the church to renew backsliders, revive families, etc.

For Hill, "any church that fails to satisfy the spiritual hunger of its members puts the church at risk". ${ }^{\text {She }}$ advocates for considerable attention to worship revitalization at the expense of all other matters. A warning is sounded regarding the Christian's responsibilities beyond the church into the civic and political affairs, which presently presents a determined threat to Christianity and freedom on the part of all to speak and act according to one's conviction. This spiritual hunger by Hill suggests a lack of prayer in the church, sound Bible teachings, deliverance which when the church lacks will cause its members to drift to other churches and this is what is exactly happening within the Ghanaian Christian Community.

\footnotetext{
Johnson K. Asamoah-Gyadu, African Charismatics: Current Development within Independent Indigenous Pentecostalism in Ghana (Accra: Africa Christian Press, 2005), 161.

Donald A. Carson, A Call to Spiritual Reformation (Michigan: Baker Book House, 1992), 72.

Christopher Buttler, In the Light of the Council (London: Darton, Longman and Todd, 1968), 71

Don H. Battley, "Charismatic Renewal: A View from Inside," Ecumenical Review 38, no. 1 (April 2010): 48

Battley, "Charismatic Renewal: A View from Inside".

Arnold Bittlinger, "Charismatic Renewal: An Opportunity for the Church?" Ecumenical Review 31, no. 3 (April 2003 ): 247.

Rob Warner, Prepare for Revival (London: Hodder and Stoughton, 1995), 169.

John Stott, The Contemporary Christian: An Urgent Plea for Double Listening (Leicester: Inter-Varsity Press, 1993$), 97$.

Monica E. Hill, The Church at Risk (Texas: Star Bible Publication, 1995), 146.
} 


\section{Spiritual Renewal and Classical Methodism}

Methodism has become a global phenomenon today. As Boafo observes:

The Wesleyan revival with its strong and evangelistic heritage has spanned more than three centuries of global Christianity and for many years to come, it will keep recurring. It should not surprise us that historians of the Pentecostal movement even trace the origins of the phenomenon to the Wesleyan heritage with its emphasis on 'enthusiasm' and Christian perfection or sanctification. ${ }^{10}$

In the work of Anderson, the demonstration of the charismata or 'spiritual gifts', has been found in all ages, albeit sometimes at the margins of the 'established' church. ${ }^{11}$ Their incidence increased during the nineteenth century, especially in the Methodist and Holiness movements and other radical Protestants who espoused similar ideas. ${ }^{12}$ The many and various revival movements at the turn of the twentieth century had the effect of creating an air of expectancy and longing for Pentecostal revival in many parts of the Protestant world. ${ }^{13}$ According to Anderson, the signs that this revival had come would be based on the "intense desire to pray, emotional confession of sins, manifestations of the coming of the spirit, successful and accelerated evangelism, and spiritual gifts to confirm that the power of the spirit had come."14

The Wesleyan revival with its strong and evangelistic heritage has spanned more than three centuries of global Christianity and for many years to come. Hence to Asamoah-Gyadu, "it is no surprise to see the recurring of these spiritual renewal programmes because the Wesleyan revival which occurred years ago still finds its impact on the Pentecostal movement today." ${ }^{15}$ In other words, these spiritual renewal programmes are not new to the church. Omenyo also shares the same view that the "Methodist does not consider spiritual renewal as extraneous or a new discovery." ${ }^{16}$ To Hollenweger, "Pentecostalism is believed to be an indirect product of Wesleyan Methodism." ${ }^{17}$ In other words, spiritual renewal as known in the Pentecostal circles as charismatic renewal is not new to the Methodist Church Ghana since Pentecostalism is one of its products.

\section{Renewal within Ghanaian Christianity}

Within the Ghanaian Christian community, the expression, "spiritual renewal," is often used to denote revival. Many churches in Ghana organize occasional revival programmes to enhance their spiritual capacities. Omenyo's analysis of the attempt of the Methodist Church Ghana (M.C.G.) at revitalizing its worship reveals that "the attempt was threatened by how the Methodist Church could integrate the renewal programmes into its traditional structures." ${ }^{\prime 18}$ Asamoah-Gyadu asserts that the way out for all the mainline churches including the Methodist Church Ghana is that "God remains sovereign. He remains the God of renewal, who determines and chooses how to carry on His mission with whatever instruments are available to him at any particular time." ${ }^{19}$ Asamoah-Gyadu solicits a response of "openness to what God is doing by His Spirit". According to him, if the history of Reformations is anything to go by, then mainline Protestant churches must be aware that if they cease to do God's bidding, "he is mighty enough to raise even stones to carry out the mission of renewal in Jesus Christ our Lord and empowered by his Holy Spirit." ${ }^{20}$ What Asamoah-Gyadu wants to drum home is that the church must open up and accept that God chooses to work in different ways.

\section{The Prayer Fellowship Movement in Ghana Methodism}

A significant impact of parachurch activity in Ghana is the rise of charismatic renewal movements in mainline Protestant churches. ${ }^{21}$ The Methodist case is the "Prayer Fellowship" movement. It emerged in the Kumasi Wesley Society (now Wesley Cathedral) through the church activism and charismatic inclinations of Isaac and Charlotte Ampah, who were both leaders

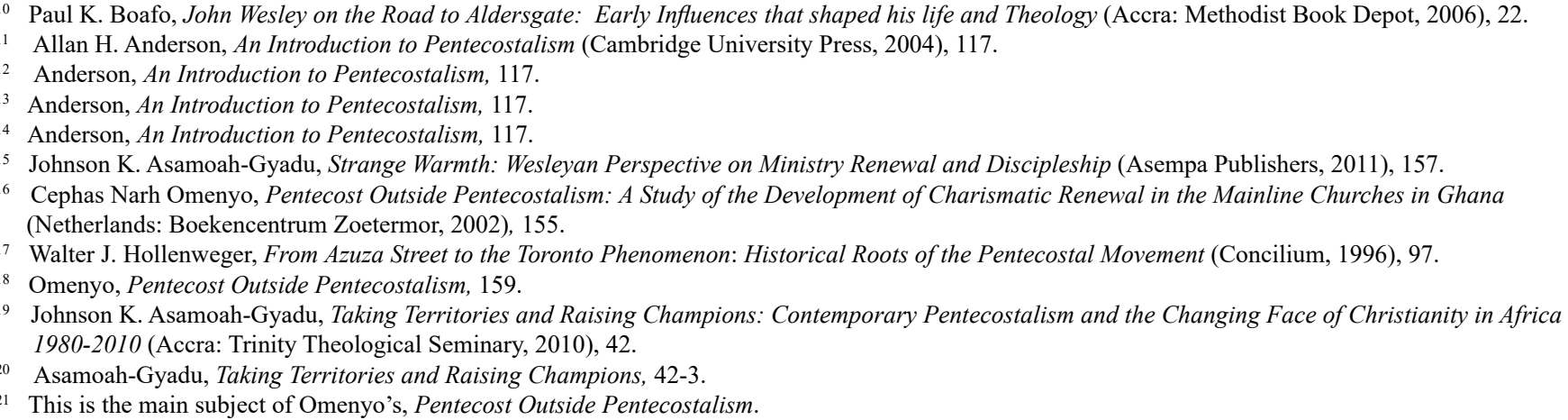


of the Church. ${ }^{22}$ Isaac Ampah was among the moderate evangelical graduates who developed an early interest in church work. He became actively involved in the Kumasi Wesley Church, submitting humbly to leaders supposedly not "born again". He qualified as a local preacher in the Kumasi Circuit of Methodist Church Ghana in the early 1970s. His active involvement in the Youth Fellowship of Kumasi Wesley Society led to his election as President of the group. He was consequently made a Church Leader - a member of the Leaders Meeting, and later appointed Assistant Society Steward. In addition to some responsibilities in the Church, he was appointed Secretary of the Evangelism, Mission and Renewal Sub-Committee of the Synod of Kumasi District (now Diocese) of the Methodist Church, Ghana.

In the mid-1970s, the Youth Fellowship became the arena of evangelical Pentecostal activity in the Methodist Church. In Kumasi Wesley Church, the last Friday of every month was devoted to all-night prayer meetings intended to arrest the drift of the youth in the church to emerging parachurch prayer fellowships. ${ }^{23}$ However, the leadership of the church as a whole was less enthusiastic about that, causing the prayer meeting to cease after a few years' experimentation. However, the Pentecostal resurgence in Ghana in the 1980s led to the resumption of the prayer meetings, a phenomenon associated with the emergent Prayer Fellowship movement.

In the early 1980s, parachurch fellowships associated with Scripture Union and the charismatic movement in Kumasi exerted considerable influence on the youth in established churches, causing many to neglect church activities. In 1982 following his training at the Haggai Institute in Singapore, Isaac Ampah was inspired to commence with his wife, Charlotte, and other Church leaders, the Wesley Prayer Fellowship (WPF). It was intended to arrest the drift of the youth in the Church to charismatic fellowships. The WPF thus commenced as a charismatic group. With an initial membership of eleven (11), and designated the "Evangelicals", the Prayer Fellowship developed into an authentic lay-ministry of Kumasi Wesley Church. It was managed by Isaac and Charlotte Ampah and supported by charismatic inclined lay-leaders of the Church, Rev. Forster Nyarko, and the Superintendent Minister, who was then Rev. Dr. Emmanuel Asante. The group conducted prayer meetings every Friday morning from 9.30 am to about $2 \mathrm{pm}$. Its meetings were conducted in a typical charismatic form - the singing of Pentecostal songs, with instrumentation, rhythmic clapping, and dancing; loud preaching, evoking "gusty yells of hallelujah" and applause, glossolalic prayers, and sessions of testimonies, healing, and deliverance. The charismatic feature of WPF meetings was given as the main factor for the dramatic increase in attendance, estimated at around 1,500 in 1990. ${ }^{24}$

The leadership of the Prayer Fellowship claimed the ministry of the group was modelled after that of Jesus Christ because it "ministers the whole gospel to the whole person - catering for individual physical, emotional and spiritual needs." 25 The "four-fold vision" of the group focused on "personal holiness; renewal...; ministering Pentecost; serving God's people".26 On the impact of the prayer meetings, Isaac Ampah claims:

Through the ministry of the Prayer, Fellowship God is transforming many lives dramatically ... Street boys and girls attracted by the gathering in the Church, come and experience the redeeming power of Jesus' love. Drug addicts come and kick the habit. Prisoners come and find the transforming power of Jesus Christ. Alcoholics come and are released from the bondage of alcohol. At a meeting, an armed robber came and surrendered his pistol. He has quit the criminal business and is now learning a new trade. In another meeting an imposter, "Azaa" man, dressed in white cassock like a priest came, having been virtually 'arrested' by the Holy Spirit. What happens there on Fridays is not by human effort. It is based on the power of the Word of God, prayer, and the love of God's children. ... Ours is a charismatic renewal. We allow the Holy Spirit to operate His gifts freely and signs and wonders to follow. Many people who are demonpossessed or oppressed come and are delivered. ${ }^{27}$

The Prayer Fellowship also responded to the social consequences of its ministry. In settling to the Christian life after conversion through the Prayer Fellowship, a converted priest of the traditional religion was assisted in finding a job and

\footnotetext{
22 Isaac and Charlotte Ampah, married since 1967, are likened to "Aquila and Priscilla" in the Book of Acts, for their corporate commitment to church and parachurch work. Ampah was a pharmacist by profession before becoming an evangelist. He was educated in Kumasi at Prempeh College and the University of Science and Technology, graduating in 1966 with B. Pharm. degree. He was a member of the Scripture Union group and the Inter-Hall Christian Fellowship of the respective institutions. After University he became a regional and national leader of the Child Evangelism Fellowship International (Ghana). For lay-Christian ministry he underwent formal training as Marriage Counsellor in a programme sponsored by the Christian Council of Ghana (1974); attended the Haggai Institute of Advanced Leadership Training, Singapore (1981); and Institute for World Evangelism (sponsored by the World Methodist Council), at Candler School of Theology, Emory University (1986-87). He thus functioned as a full-time evangelist, marriage and family life counsellor. Charlotte Ampah, a teacher by profession, and later ordained as a minister of Methodist Church Ghana, was educated at Holy Child Secondary School, Cape Coast, and Wesley College, Kumasi. She was a product of the Faith School of Evangelism (established by the Faith Convention Movement in Kumasi in the early eighties) and Christian Service University College where she obtained Diploma in Theology (1993-95), BA Theology (1991-2001) and Postgraduate Certificate in Christian Ministry with Management (2013-2014). She was a popular speaker at charismatic meetings in both church and parachurch contexts.

23 Early examples of such prayer fellowships are the Upper Room Fellowship in Kumasi and Ghana Evangelical Society in Accra, see Smuel B. Adubofuor, "Evangelical Parachurch Movements in Ghanaian Christianity, c1950s-1990s" (PhD Thesis, University of Edinburgh, 1994), Chapter Four.

24 "Report on Methodist Prayer Fellowship," Proceedings of 29th Annual Synod of Kumasi District of Methodist Church - Ghana, at Old Tafo, 17-21 May 1990, Representative Session, 142.

25 Adubofuor, Parachurch Movements in Ghana, 437 (from Interview with Isaac Ampah).

26 Isaac Ampah, "Signs and Wonders at Wesley Church: A Report on the Prayer Fellowship," Wesley News, Newsletter of Kumasi Wesley Church, (January -March, 1990): 5.

27 Ampah, "Signs and Wonders at Wesley Church," 5-6.
} 
accommodation. After completing a rehabilitation programme, a blind man was re-settled as a cane weaver.

The Prayer Fellowship became an emergent charismatic movement in Ghana Methodism. Their activities included monthly all-night prayer meetings and weekly healing and deliverance services and retreats. Members were encouraged to fast and pray for each other and the Church as a whole. The paramount interest of the Fellowship in evangelism was a prime factor for the rise of charismatic evangelists in the Methodist Church Ghana. From Kumasi Wesley Church, Opanin S.K. Danso, Kumasi Circuit Steward (1983-90), a charismatic lay-preacher and President of Subin Chapter of Full Gospel Business Men's Fellowship International (Ghana), was trained and designated Kumasi District Evangelist of Methodist Church of Ghana. ${ }^{28}$

The charismatic impact of the Prayer Fellowship movement in the Kumasi Wesley Society inspired the emergence of other Fellowships with their evangelists, prophets, and prophetesses in congregations of other Methodist circuits in Ashanti. In 1990 the Evangelism Group of Bantama Circuit was inaugurated in Kumasi in a ceremony during which Joseph Otsin was commissioned "as the first-ever full-time evangelist" of the Methodist Church Ghana. ${ }^{29}$ Circuit reports indicate the formation of a Central Prayer Band; the commencement of Friday healing and deliverance service/retreats in Achinakrom Circuit; Friday morning prayer meetings at Suame and New Tafo, incorporating monthly all-night prayer meetings at Amakom; Sunday evening healing services, with cases of exorcism in Obuasi, extending to Edubiase; and prayer and evangelistic exercises in Offinso. ${ }^{30}$ Members of the Methodist prayer movement were encouraged to fast and pray for each other's needs and the Church as a whole.

In Ashanti where it originated, the Prayer Fellowship movement gained ecclesiastical recognition as a Church organization, as "a vital force in evangelization... and renewal". ${ }^{31}$ It was a recognition that involved regulation. The need to regulate the operations of the Fellowship was the main objective for organizing deliverance workshops for the leadership, as indicated by the following notice:

The Chairman of the Kumasi District of the Methodist Church Ghana ... invites all Evangelists, Prophetess and Prayer Fellowship leaders under its wing to a three-day deliverance workshop ... at the Freeman College, from the 14-17 December 1989. ... The Rev. Chairman expects all Prayer Fellowships in the Methodist Church in Ashanti Region to send representatives to this workshop."32

The cumulative effect of the operations of the prayer movement was the revitalization of faith, evident in increased church attendance and renewed zeal for evangelism.

Although there was an increasing adult interest, the charismatic movement was a phenomenon generally associated with the youth in the Church. In asserting that "Methodism is not dead", some observers pointed to the Ghana Methodist Students Union (G.H.A.M.S.U.) to prove "the spirit of [Ghana] Methodism is alive and kicking, ..." ${ }^{33}$ At the 24th Annual Conference of G.H.A.M.S.U. at the University of Cape Coast, as "students were singing praises and loudly praying, some adherents of the Church expressed concern as they asked each other: 'has the Church now come to this or are we [Methodists] ... now turned Pentecostal?"'34 In a symposium on "Exodus of the Youth" to Charismatic Churches, by the Youth Fellowship of Accra Wesley Church, it was suggested the orthodox churches modify their liturgy to reflect the growing charismatic interest. ${ }^{35}$ The eagerness to accommodate charismatic elements and arrest the attraction of the youth to independent charismatic churches was a major factor for the introduction of the "Youth Service" and "Deliverance Service" in some Methodist and Presbyterian churches. ${ }^{36}$

\section{The Deliverance Service}

In Ghana today the deliverance ministry is undertaken by evangelical Pentecostal/charismatic churches and fellowships with the recognition that the desire for healing and deliverance directed many church members to cultic shrines of the traditional religion and to prophets and prophetesses of the Independent African Churches called "Spiritual Churches". In some congregations of the Methodist Church Ghana, the operations of the Prayer Fellowship movement led to the

\footnotetext{
28 Between 1989-90 Opanin Danso was sponsored by the Methodist Church-Ghana for training at the World Institute of Evangelism, Candler School of Theology, Emory University - Atlanta, Georgia (USA).

29 Methodist Times 4, no. 2 (June 1990): 3. The Bantama Evangelism Group was consecrated by Rev Frank Derker (then Evangelism Director of the Methodist Church Ghana), assisted by Rev. S.E.A. Quarm, Supt. Minister of the local Circuit. Evangelist Otsin now co-ordinates evangelistic activities of Methodist Church Ghana in collaboration with United Methodist Church, USA.

30 Proceedings of 29th Synod, passim.

31 Proceedings of 29th Synod, passim.

32 Isaac K. Ampah, "Workshop for Prayer Fellowship Leaders Under the Kumasi District of the Methodist Church, Ghana," Circular to Prayer Fellowship Secretaries, $1989,1$.

33 Methodist Times 3, no. 3 (Dec. 1989): 4.

34 Methodist Times 3, no. 3 (Dec. 1989): 4.

35 Methodist Times 3, no. 3 (Dec. 1989): 2. Cf. "Curbing the Youth Drift," Methodist Times 4, no. 1 (January 1990): 2, advocates a charismatic model, incorporating: "sessions of praises and worship, word ministrations, altar call and testimonies".

36 The "Youth Service" which was conducted in English, was already in operation in some city churches, e.g. Ramseyer Presbyterian Church (Kumasi), and Mount Olivet Methodist Church, Dansoman, Accra; Methodist Times 4, no.1 (January 1990): 2.
} 
recognition of deliverance ministry. In Kumasi Wesley Methodist Church such recognition led to the introduction of a monthly "Deliverance Service" on 4 February 1990, in an attempt to meet the "special" spiritual needs of members that could not be attended to in the regular Sunday divine service. ${ }^{37}$ In addition to announcements in the Church, and in line with current trends, the first service was advertised with handbills as follows:
"Methodist Church, Ghana, Deliverance Service,
Every first Sunday of each month,
Commencing - Sunday 4 February 1990
Venue - Kumasi Wesley Methodist Church
Time: 6 - 8pm.
Anointed Men of God: Senior Ministers and Charismatic leaders in the Church
(Isaac and Charlotte Ampah, and S.K. Danso - F.G.B.M.F.I. leader) will minister.
The sick, the afflicted, the troubled are invited for healing and deliverance.
See Jesus' saving power." ${ }^{38}$

The service attracted a large attendance, around 500, with most of the time devoted to praying for those who proceeded forward to receive prayer. Ministers and Church leaders assigned for the evening prayed, laying hands on over 200 individuals. The Deliverance Service was in an experimental stage, but it was an authentic response of the Methodist Church to the supernatural worldview and charismatic interest of its membership.

\section{The "Aldersgate Week" and the Charismatic Significance of John Wesley}

One product of the Pentecostal/charismatic influence in the Kumasi Methodist Church is the institution of "Aldersgate Week". The "Aldersgate Week" meetings in Ghana Methodism derive from the observance of 24 May as "John Wesley Day". The day is observed to commemorate Wesley's spiritual experience on 24 May 1738, particularly that relating to a meeting at Aldersgate Street in London. The day commenced at $5.00 \mathrm{am}$ with a reading of passages in the Greek New Testament, as his custom was. ${ }^{39}$ In the afternoon he accompanied a friend to an "evensong" at St Paul's Cathedral, where he heard the choir render an anthem: "Out of the deep have I called unto Thee, O Lord". ${ }^{40}$ Wesley's experience climaxed that evening with his presence at a Moravian meeting in Aldersgate Street in the City. There was a reading of Luther's Preface to the Epistle to the Romans. Wesley describes his personal experience that evening as follows:

About a quarter before nine, while he was describing the change which God works in the heart through faith in Christ,

I felt my heart strangely warmed. I felt I did trust in Christ, Christ alone for salvation; and an assurance was given to me that he had taken away $m y$ sins and even mine, and saved $m e$ from the law of sin and death. ${ }^{41}$

There are variant interpretations of Wesley's experience at Aldersgate: either as his "conversion-experience" 42 or as a confirmation or continuation of a process (of faith development) which had commenced at Oxford. Wesley's unique experience at Aldersgate was a climax of what commenced at St. Paul's, though the interpretations given to the former overshadow the significance of the latter.

Methodists in Ghana commemorate Wesley's Aldersgate experience with special evening meetings in churches and schools, and service on Sunday immediately following 24 May. Evangelistic addresses are given to secure conversions. Many Ghanaian evangelicals refer to Wesley's Aldersgate experience as "conversion-experience", and advocate evangelical conversion (or second conversion) of people already established in the Church, even as leaders or ministers. The charismatics identify Aldersgate with "spiritual/faith renewal", and describe John Wesley as "evangelical and a Pentecostal".33 This is reflected in a call for renewal:

Today as we celebrate the 250th anniversary of John Wesley's conversion, let us pause and soberly reflect ... Methodism has lost its savour and we do not see the power thereon. Our pulpits are filled with preachers who preach "fairy tales". Class meetings are led by leaders who are not spirit-filled. The causes of such a divergence are to be found in the neglect of the old-time religion. ... We say John Wesley was evangelical and a Pentecostal, but what do we see here a

\footnotetext{
37 Wesley News 1, no. 2 (January - March, 1990): 10. The Deliverance Service was also a revival of the "Monthly Evening Healing Service" initiated in the 1970s but had declined in the early 1980 s.

38 Kumasi Wesley Church Deliverance Service handbill, 1990.

39 He started with II Peter 1:4, and later Mark 12:34.

40 Martin Schmidt, John Wesley: A Theological Biography (Epworth: London, 1962), 262, states the words of the anthem were from Psalm 130. Its appeal to Wesley is indicated by the fact that he wrote out the words of anthem in full in his Journal 1, 147.

41 Wesley's Journal 1, 475-6.

42 Schmidt, John Wesley, 263; cf. R.G. Tuttle Jr, John Wesley: His Life and Theology (Zondervan: Grand Rapids, 1978), $193-201$.

43 Elizabeth Dodge Tyson, “An Analysis of Neo-Pentecostal Mission Theology 1960-90: Four Case Studies” (PhD Thesis, University of Edinburgh, 1993), 5, states: "Wesley's insistence on the palpable 'witness of the spirit' earned him the contemptible label of an 'enthusiast'. Some of Wesley's theological emphasis are similar to that of present day Pentecostalism. The pneumatology apparent in the writings of John Wesley foreshadow the pneumatology advocated by twentieth century Pentecostals."
} 
cold and lack-luster Church ... sustained by the faithful few who are filled by the Holy Spirit. To bring the religion of the old times then there is the need to allow the fullest of the Holy Spirit operation in our Church. The time has come for us to uproot any witchcraft spirit, principalities, and secretism (lodges) assigned to rule over our Church....stand in readiness for combat and resist every strategy of that fallen enemy, Satan... ${ }^{44}$

The association of John Wesley with Pentecostalism was intended to validate the charismatic movement in Ghana Methodism, and establish a legitimate ground for the Methodist Church Ghana to be more charismatic. In calling for the Church to exhibit the presence and control of the Holy Spirit, a charismatic enthusiast remarks: "As present-day Methodists, we still do have the structure and set up of John Wesley but not his charisma."45 A group self-designated: "Methodist Revival Movement", therefore, called on the Church to initiate Wednesday prayer and fasting for "revival in the Methodist Church as in the days of ... John and Charles Wesley." ${ }^{36}$ For the charismatic Methodists, John Wesley is a Pentecostal fore-bearer of the Christian faith.

The charismatic trend in Kumasi Wesley Society led to an extended observance, and the transformation of "John Wesley Day" to "John Wesley Week" - designated "Aldersgate Week". Events of the Week: morning and evening sessions of prayer, Bible addresses, and testimony sharing, are intended to project the charismatic significance of John Wesley's Aldersgate experience. The 21-25 May 1990 programme, code-named “Aldersgate and You”, emphasized: “This Year's John Wesley's Week is a week for spiritual renewal", with focus on the blessings of God for the believer ${ }^{47}$ Methodist ministers and lay preachers engaged as "anointed speakers" for the daily meetings (9am - 12noon and 6.30-8.00pm) included: Rev. Dr. S. Asante Antwi (then Chairman of Methodist District of Kumasi), Rev. Dr. Emmanuel Asante (Superintendent Minister of Kumasi Methodist Circuit), Rev. Kofi Amponsah (Principal, Wesley College, Kumasi), Rev. Grace Nnuro (Principal, Kwadaso Women's Training Centre), S.K. Danso (Kumasi Methodist Circuit Steward) and Isaac and Charlotte Ampah. ${ }^{48}$ As a special attraction to the Aldersgate event, it was arranged for Nana Ama Owusuaa (a converted priestess of the traditional religion) to give a testimony. Being a Methodist charismatic movement, the operations of the Prayer Fellowship of Kumasi Wesley Church incorporated the "Aldersgate Week". The charismatic significance of the event was extended to members of other denominations who attended the Friday meetings of the Prayer Fellowship. It is estimated around 2000 attended the Friday morning prayer meeting of the "Aldersgate Week".

In the observance of the "Aldersgate Week" and recurrent references to John Wesley as Pentecostal/charismatic, the charismatics of the Methodist Church Ghana make an emphatic statement that historic Methodism has charismatic traditions or features which give grounds for the current movement towards charismatism. To the charismatics the Methodist Church is charismatic, implying one can be an authentic Methodist and charismatic at the same time.

\section{The Methodist Prayer Renewal Programme}

Omenyo observes: "To a large extent the Wesley Prayer Fellowship (WPF), Kumasi by all standards had influenced a lot of Methodist Churches in Kumasi Diocese on renewal lines." ${ }^{49}$ The Kumasi Friday prayer fellowship which later became a movement eventually metamorphosed into Methodist Prayer Renewal Programme, a charismatic renewal movement in Methodist Church Ghana.

In the 1990s it was observed that the Methodist Church Ghana "lacked spiritual power." ${ }^{50}$ The usual prayer meetings in the societies had become "dull stereotypes and uninspiring and nominalism was gaining roots." ${ }^{51}$ According to Kudadjie, "John Wesley encouraged his followers to pray and fast on Wednesday and Fridays, and the result was that the church of his time was spiritually revitalized." ${ }^{52}$ The Methodist Church Ghana thus felt the need for a spiritual renewal to recover the fervor of prayer ministry in the Church. Considering the central place that prayer occupied in the life of the early Methodists, a decision was taken by the Church to investigate and find out more about the prayer fellowships that had sprung up in the societies.

In 1991 Rev. Dr. S. Asante-Antwi, then Chairman of Kumasi District of Methodist Church Ghana, invited the President of Conference, Rt. Rev. Professor Kwesi Dickson to pay a visit to the Prayer Fellowships in Kumasi. ${ }^{53}$ The

44 Methodist Times 2, no. 5 (October 1988): 4.

45 James F. Bilson, "Why the Youth Drift," Methodist Times 3, no.1 (May-June 1989): 4.

46 Methodist Times 4, no.1 (June 1990): 5. In a press interview, Rt. Rev. Prof. K.A. Dickson (President of the Conference of Methodist Church - Ghana) offered a response to the charismatic demands by re-stating some general notions of evangelicalism and Pentecostalism, and concluding that the Methodist Church is essentially evangelical and Pentecostal. But the charismatics had no such perceptions of the Church. See Methodist Times 4, no. 5 (December 1990 ): 4.

47 Isaac K. Ampah, "Aldersgate and You” (21-25 May, 1990), Notice to Leaders of Kumasi Wesley Methodist Church, 3 May $1990,1$.

48 Ampah, "Aldersgate and You," 1.

49 Omenyo, Pentecost Outside Pentecostalism, 159.

50 Joshua N. Kudadjie, "The Relevance of the Methodist Prayer and Renewal Programme" (paper presented at the Accra District of the Methodist Church Ghana Consultation on Evangelism, January 28- 30, 1999), 2-3.

51 Kudadjie, "Relevance of the Methodist Prayer and Renewal Programme," 2.

52 Charlotte Ampah, "The Genesis of the Methodist Prayer and Renewal Programme and its Role in the Bantama Ebenezer Methodist Church," (Dip. Th. Long Essay, Christian Service College, 2001), 32-33.

53 Adubofuor, "Evangelical Para-Church Movements, ” 432. 
President upon getting firsthand information on the Fellowships tasked the Committee on Evangelism, Mission, and Renewal to undertake a critical study of the whole phenomenon of prayer fellowships in the entire Methodist Connexion. Professor Dickson realized the attendance of the fellowship meetings was remarkable but it also came along with peculiar problems. According to Paul K. Boafo, "the President requested that studies be made into the fellowships which were widely gaining root within the District of Kumasi not because he hated their activities but to help the Connexion provide proper training and support for the fellowships which had become a phenomenon within the Kumasi District." ${ }^{\prime 4}$

The committee visited the Wesley Methodist Prayer Fellowship, Adum - Kumasi, to assess the situation. They observed instances of "excesses and emotional outbursts while there was also strong evidence of growth, revival, and testimonies." ${ }^{55}$ The Committee's report also revealed the Church had a divided opinion on the prayer fellowships. According to Charlotte Ampah, those who felt there was no need for the church to recognize those prayer fellowships argued that:

i. There was a tendency for the prayer fellowships to adopt non-Methodist teachings and practices.

ii. The traditional Methodist prayer meetings like morning devotions existed. They could be revived and integrated with activities such as prayer for personal needs including healing, and testimony time.

iii. Ordained ministers in the church could be made more active in the prayer meetings since it was mostly left in the hands of the caretakers and few evangelists. ${ }^{56}$

Those who advocated the recognition of the fellowships observed that:

i. The conventional prayer meetings had lost their vitality and could meet the current needs of members.

ii. The stagnation in the church growth was primarily due to its impoverished prayer life.

iii. With the inception of the prayer fellowships, there had been no exodus of membership from the Church. On the contrary, there has been a revival of spiritual life and growth in material resources of the Church. ${ }^{57}$

During the $32^{\text {nd }}$ Connexional Conference of Methodist Church Ghana held in Accra in 1993, an ad-hoc committee led by Rev. Prof Joshua Kudadjie was formed to critically study the justification for spiritual renewal programmes and submit a report to the Law and Polity Committee for consideration. The findings of the committee led by Rev. Prof. Joshua Kudadjie produced evidence that supported the arguments of both sides of the debate.

It found (1) that the traditional prayer meetings were not altogether dead and that revival in prayer life was necessary for all and not just some members of the Church; (2) that there was some amount of "disorder" as well as an excessive emotional outburst in some of the fellowships; and (3) that some of them did adopt "un-Methodist" teachings and practices - as the opponents had maintained. On the other hand, there was ample evidence in favour of the fellowships. For instance, (1) in many cases, the conventional prayer meeting had lost its vitality and could not meet the needs of members. In contrast, (2) the prayer fellowships were meeting the needs of the people and making manifest the power of Jesus Christ, as evidenced in conversions, healings, prophecies, and deliverances. Again, (3) in Societies where they operated, there was a revival and growth in both the material and spiritual resources of the Church..$^{58}$

Despite the opposing views, the Committee observed that there was a quest for renewal in the whole Connextional Church because:

There have been complaints about the church's poor prayer life, lack of adequate relevant biblical teaching and manifestation of the gifts of the Holy Spirit, etc. Some members especially the youth and the women have left the church, while others maintain a dual membership, clandestinely associating with other churches to satisfy their spiritual hunger. The Methodist Prayer Fellowships have emerged in the church as one of several sincere initiatives by some faithful Methodists to revitalize the spiritual life of the church. Some of these Prayer Fellowships operate within the church but others have since become independent. ${ }^{59}$

In an effort towards formalization and standardization, the leadership of the Prayer Fellowship movement was requested to submit a draft constitution covering the Fellowship and its activities. According to Very Rev. Kwaku Kwarteng, when they presented the draft constitution to the M.C.G. Conference for adoption, "it was rejected on the basis that there could be only one constitution for the Methodist Church Ghana, all others must be bye-laws." ${ }^{00}$ The ad-hoc committee was unable to recommend the draft constitution for adoption by Conference, because "the Committee felt the Prayer Fellowship should not be a separate movement (organization) in the church but could operate under a wing of the

54 An interview with Very Rev. Dr. Paul K. Boafo, August $17^{\text {th }} 2015$. He is now the Presiding Bishop of Methodist Church Ghana.

55 Resource Manual of Evangelism, Mission and Renewal Sub-division of the Methodist Church Ghana, 11.

Ampah, "The Genesis of the Methodist Prayer and Renewal Programme," 39.

Ampah, "The Genesis of the Methodist Prayer and Renewal Programme," 39-40.

Omenyo, Pentecost Outside Pentecostalism, 165.

59 Resource Manual, 13.

60 Hosea Osei, interview with Very Rev. Kwaku Kwarteng, Supt. Minister, Suame Circuit, MCG, August $20,2015$. 
Church." ${ }^{1}$

During the $33^{\text {rd }}$ Methodist Conference in Kumasi, $18^{\text {th }}-23^{\text {rd }}$ August 1994, the Law and Polity Committee met three times to consider the report of the Adhoc Committee. The outcome was that "the prayer fellowship must operate under the Evangelism Mission and Renewal Division of the Board of Ministries." ${ }^{2}$ Thus it was at the $33^{\text {rd }}$ Conference (1994) that the Prayer Fellowship was officially accepted and designated Methodist Prayer and Renewal Programme (M.P.R.P) to operate under the following guidelines:

The Church shall budget for the programme

The programme shall not operate as a distinct organization in the church with membership, uniforms, payment of dues. A special account for the programme shall be opened in each of the societies and the minister in charge of the society shall be a compulsory signatory to the accounts of the programme. ${ }^{63}$

In the same Conference year (1994), it was agreed the programme be allowed to operate on five tracks: Prayer and Worship, Teaching and Discipleship, Healing and Counseling, Evangelism and Preaching, Welfare and Social Action. ${ }^{64}$

\section{Activities of Methodist Prayer and Renewal Programme}

There is no uniform practice throughout the Church for the M.P.R.P., but there are some major activities of the Methodist Prayer and Renewal Programme that cut across various centers. Bible study is an integral activity of the Methodist Prayer and Renewal Programme. According to Omenyo, "Bible study is to help members read and study the Bible seriously and with an open mind to grow in grace and help one another in our Christian development and social life (cf. 2 Timothy 2:13)." ${ }^{\prime 5}$ There were times members were divided into groups for bible teachings to make it more effective. It was done to help members live an effective Christian life. The meetings of the Methodist Prayer and Renewal Programme are often held from 8:30 am to 12:30 pm, with 8:30 am to 9:30 am as the period for Bible study moderated by a leader who directs questions to members to facilitate discussion. After each study, members are encouraged to memorize a Bible text to consolidate their faith in Christ. Some of the popular topics for the Bible studies are salvation, the Holy Spirit, spiritual warfare, deliverance, eschatology, and evangelism.

\section{Exorcism and Deliverance Sessions}

Exorcism is a pervasive religious practice in virtually every brand of Christianity in Ghana represented by the Pentecostal, charismatic and historic churches. According to Ampong and Benyah, "exorcism is mostly an extended version of deliverance," ${ }^{16}$ but some Christians have established a distinction between the two. Exorcism is regarded as "a specific act of binding and releasing, performed on a person who is believed to be possessed by a non-human malevolent spirit." ${ }^{67}$ Deliverance on the other hand is the general idea of "freeing people from the bondage of Satan." ${ }^{8}$ In certain situations, deliverance may involve exorcism, but generally, it does not. ${ }^{69}$

In the words of Omenyo, "the beliefs associated with Satan and demons have made the practice of warding off and casting out Satan and demons prominent among charismatic groups in Ghana."70 This observation has become acute as non-Christian elements of African Traditional Religion are often demonized and mixed-up with mystical forces of evil in the Bible. ${ }^{71}$ As with most Ghanaian evangelicals, deliverance activists associate deities of the traditional religion with demons and condemn cultic acts and rites including libation as demon worship. The traditional belief that deities are viceroys of Nyankopon (God in Akan belief) is rejected. ${ }^{72}$ Their concept of witchcraft is influenced by their reading of the Bible and the Akan cosmological context of their operation. The deliverance workers assert witchcraft occurs in the Bible, with Satan as the primary source. Closely linked with this teaching is the belief in a hierarchy of evil spirits with intelligence, memory, will, emotions, and pride, who are associated with all the negative temperaments displayed by humans. ${ }^{73}$ It is believed they possess human beings and function through them.

\footnotetext{
Resource manual, 13.

62 Ampah, "The Genesis of the Methodist Prayer and Renewal Programme," 40; Doris E. Yalley, "Ghanaian Methodist Spirituality in Relation with Neo-Pentecostalism," Ghana Journal of Religion and Theology 8, no. 1 (2018): 134.

63 Ampah, "The Genesis of the Methodist Prayer and Renewal Programme," 40; Hosea Osei, "Spiritual Renewal Programmes in Ghanaian Christianity: The Approach of the Methodist Church Ghana, Kumasi Diocese" (MA diss., Christian Service University College, 2016 ), 35.

${ }^{64}$ Hosea Osei, "Spiritual Renewal Programmes," 35; Yalley, "Ghanaian Methodist Spirituality," 134.

65 Omenyo, Pentecost Outside Pentecostalism, 248.

${ }^{66}$ Ebenezer A. Ampong and Francis Benyah, "Imposition of Hands: A Theological Assessment of Contemporary Ghanaian Christian Exorcistic Practice," Trinity Journal of Church and Theology 19, no. 1 (March 2017): 86

67 Ampong and Benyah, "Imposition of Hands," 86.

68 Ampong and Benyah, "Imposition of Hands," 86.

Ampong and Benyah, "Imposition of Hands," 86.

Omenyo, Pentecost Outside Pentecostalism, 255.

Opoku Onyinah, "Akan Witchcraft and the Concept of Exorcism in The Church of Pentecost" (PhD Thesis, University of Birmingham, 2002).

I Cor. 10:20 is used as a Biblical ground.

Cf. Ephesians 6:12.
} 
Exorcism is generally perceived as a spiritual battle with a hierarchy of spiritual powers of evil, including witchcraft. In this spiritual engagement, Christological concepts are employed to fortify the Christian combatants. The members of the M.P.R.P. derive confidence from Christian belief in the residence of the Spirit of Christ in believers, to assert combat superiority over witches and demons. Particular reference is made to the statement of scripture: "...the one who is in you is greater than the one who is greater than the one who is in the world", ${ }^{\prime 4}$ to assert that the spirit of Christ is greater than witchcraft. The group perceives witches as powerless over Christians, and so consider themselves immune to witchcraft attacks. Although the teachings of M.P.R.P. make members develop an acute awareness of the presence of witches wherever they might be, they are not terrorized by such awareness. In their preaching, the group takes an offensive stand in confronting and challenging demonic spirits and witches perceived to be present.

During the M.P.R.P. meetings, people who are believed to be oppressed by evil spirits undergo deliverance through exorcism. During such sessions, there are a lot of physical manifestations such as vomiting; urinating; rapid rolling of the eye-balls, crawling on the ground, bizarre bodily movement, bad odor, shedding of tears, laughing and roaring. ${ }^{75}$ In difficult or extreme situations, such people are led out of the meeting place for a deliverance team designated "prayer warriors" to handle them. Anointing oil is applied during the session to deliver the afflicted. There is a fair uniformity in the practice of deliverance because the deliverance workers are regular participants in the deliverance workshops organized by the Prayer Warriors Ministry of the Scripture Union (S.U.) Ghana. ${ }^{76}$

The M.P.R.P. prayer meetings involve speaking in tongues, clapping of hands, and stamping of the feet in prayer. $^{77}$ Members are normally seen seriously moving about in prayer whiles music instrumentalists play various musical instruments alongside the prayer. In the course of the prayers, people who are sick are brought to the front for the leader to lay hands on them with the support of the prayer team. In cases where it is considered necessary to anoint the sick individual with oil, it is done based on the instruction in James 5:14-15 which says: "Is any among you sick? Let him call for the elders of the church, and let them pray over him, anointing him with oil in the name of the Lord; and the prayer of faith will save the sick man, and the Lord will raise him up; ..." (N.I.V.).

\section{Sharing of Personal Testimonies}

In the M.P.R.P., provision is made for testimony sharing for participants to present what the Lord Jesus has done for them through the Programme. Those who share the testimonies also willingly make modest offerings as an indication of their appreciation to God. Testimony sharing constitutes an important aspect of Pentecostal worship in Ghana. ${ }^{78}$ For the M.P.R.P. members, the personal testimonies serve as evidence of God's existence and his direct involvement in individual human affairs. In evangelism testimonies of spectacular Christian conversions demonstrate the power of God and emphasize the gravity of one's un-Christian past as godless, criminal, or immoral. However, such preferences have led to the projection and glorification of the pre-Christian experiences and lifestyles, sometimes recounted with some fantastic exaggerations.

The impact of the activities of the Methodist Prayer and Renewal Programme on both the church and the individuals has been tremendous. The church has seen a fresh awakening in its prayer life and giving. The attendance of prayer meetings has been encouraging, whiles the giving of offering has also improved. The cumulative effect is the increase in numerical strength of the Church. This is because the programme attracts both Methodists and non-Methodists, with some of those who did not belong to any church eventually remaining in the Church. Also the M.P.R.P. is a principal factor for converting non-Christian attendees into the Kingdom of God. Many experience breakthroughs in their predicaments through the programme. A young lady at Asawasi Methodist called Cynthia Acquah was able to conceive and gave birth after five years of childlessness in marriage when Evangelist Kwadwo Boateng was ministering. ${ }^{79}$ These are pieces of evidence that M.P.R.P. is being operated according to its mandate.

\section{Pentecostalism and African Spirituality}

The accounts about the Methodist Prayer Fellowship and its transmogrification into the Methodist Prayer and Renewal Movement project the interface between Pentecostalism and African spirituality. For the African the world is a mystery. There are so many occurrences in the world that the African finds scientifically inexplicable, but religiously understandable through the belief in supra-human and superhuman beings and spirits. According to Asante, "these

\footnotetext{
4 I John 4:4 (NIV)

Abamfo Atiemo, "Deliverance in the Charismatic Churches in Ghana," Trinity Journal of Church and Theology 4, (1994-1995): 42.

Adubofuor, "Evangelical Para-Church Movements, ” 228-44.

For a detailed study of hand-clapping in prayer, see Ebenezer A. Ampong, "Doctrine or Experience? A Theological Assessment of Persistent Hand-Clapping in Contemporary Ghanaian Christian Prayer," Ghana Journal of Religion and Theology 8, no. 1 (2018): 49-66.

78 The Full Gospel Men's Fellowship International in Ghana concentrates attention on personal testimonies as an alternative form of evangelistic preaching. See Adubofuor, "Evangelical Parachurch Movements," 390-1.

79 Osei, "Spiritual Renewal Programmes," 37-8.
} 
inform the spirituality of the African Christian ..." ${ }^{80}$ Furthermore, as Asante observes: "majority of Christians in Africa believe that life and, for that matter, the Christian life is, among other things, a warfare involving seen and unseen spiritual forces." ${ }^{11}$ The church activities like the M.P.R.P. are thus intended to overcome these forces through "intense religiosity, involving prayer, fasting, reading and meditating on the Word of God, and opening up to the empowerment of the Holy Spirit." ${ }^{2}$ Asante thus calls on the Church in Africa to "give a liturgical and theological space for the intense religiosity of the African." ${ }^{3}$

\section{CONCLUSION}

The exposition presented in the foregoing indicates prayer is central to the spirituality of Methodists in Ghana, with many of the Methodist churches thriving on prayer. This explains the proliferation of prayer activities within the Church at

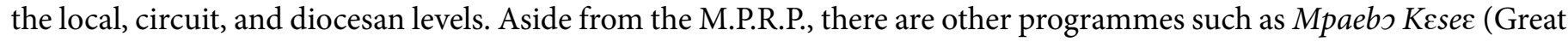
Prayer), "Prophetic Convention", "Diocesan All-Night Prayer", "Good Morning, Holy Spirit", and "PUSH" (Pray Until Something Happens), with the last two currently trending in Kumasi. All these are supplements to the regular Sunday church worship programmes. It confirms the observation that church life in Africa is "characterized by spiritual fervor and intense spirituality, which is concretized in active church attendance, fervency of prayer, and active evangelism." ${ }^{84}$

The centrality of prayer to African Christian spirituality is driven by the African worldview which is characterized by multifarious spiritual and mystical forces constantly exerting malevolent influence on daily life. The Ghanaian saying that "life is war" is an engagement with spiritual combatants in which the Christians use prayer to deploy verbal assault weapons to launch attacks on their unseen enemies and also defend themselves.

The African reality which is also characterized by socio-economic woes makes prayer indispensable.In the struggle to cope with or better still overcome the vicissitudes of life, prayer becomes a means to secure divine aid. Thus for survival in life, spiritually and physically, prayer for the African Christian, particularly the Ghanaian, is indispensable. Hence the multiplicity of prayer groups and activities in Ghanaian Christianity.

\section{ABOUT AUTHORS}

Samuel B. Adubofour, $\mathrm{PhD}$, is a Senior Lecturer at the Department of Theology, Christian Service University College where he teaches Missions, Evangelism and Church Growth courses. He is also Dean, Faculty of Humanities, Christian Service University College, Kumasi, Ghana.

Hosea Osei, MA, is a Ministerial Candidate of Methodist Church Ghana.

\section{BIBLIOGRAPHY}

Adubofuor, S.B. "Evangelical Parachurch Movements in Ghanaian Christianity, c1950s-1990s." PhD Thesis, University of Edinburgh, 1994.

Ampah, Charlotte. "The Genesis of the Methodist Prayer and Renewal Programme and its Role in the Bantama Ebenezer Methodist Church.” Dip. Th. Long Essay, Christian Service College, 2001.

Ampah, I.K. "Signs and Wonders at Wesley Church: A Report on the Prayer Fellowship," Wesley News, Newsletter of Kumasi Wesley Church (January - March, 1990): 5-6.

Ampah, I. K. "Aldersgate and You" (21-25 May, 1990). Notice to Leaders of Kumasi Wesley Methodist Church. Typescript. 3 May 1990.

Ampah, I.K. "Workshop for Prayer Fellowship Leaders under the Kumasi District of the Methodist Church, Ghana," Circular to Prayer Fellowship Secretaries, 1989.

Ampong, E. A. "Doctrine or Experience? A Theological Assessment of Persistent Hand-Clapping in Contemporary Ghanaian Christian Prayer." Ghana Journal of Religion and Theology 8, no. 1 (2018): 49-66.

Ampong, E.A. and F. Benyah. "Imposition of Hands: A Theological Assessment of Contemporary Ghanaian Christian Exorcistic Practice." Trinity Journal of Church and Theology 19, no. 1 (March 2017): 84-108.

Anderson, A. An Introduction to Pentecostalism (Cambridge University Press, 2004).

\footnotetext{
80 Emmanuel Asante, Issues in African Traditional Religion, Humanities, Ethnicity and Development: Impact on African Christianity (Accra: Sonlife Press, 2017), 35.

81 Asante, Issues in African Traditional Religion, 35.

82 Asante, Issues in African Traditional Religion 35.

83 Asante, Issues in African Traditional Religion 45.

84 Asante, Issues in African Traditional Religion, 45.
} 
Asamoah-Gyadu, J. K. Strange Warmth: Wesleyan Perspective on Ministry Renewal and Discipleship. Asempa Publishers, 2011.

Asamoah-Gyadu, J. K. Taking Territories and Raising Champions: Contemporary Pentecostalism and the Changing Face of Christianity in Africa 1980-2010. Accra: Trinity Theological Seminary, 2010.

Asamoah-Gyadu, J.K. African Charismatics: Current Development within Independent Indigenous Pentecostalism in Ghana. Accra: Africa Christian Press, 2005.

Asante, Emmanuel. Issues in African Traditional Religion, Humanities, Ethnicity and Development: Impact on African Christianity. Accra: Sonlife Press, 2017.

Atiemo, Abamfo. "Deliverance in the Charismatic Churches in Ghana." Trinity Journal of Church and Theology 4 , (1994-1995): 39-49.

Battley, D. H. "Charismatic Renewal: A View from Inside." Ecumenical Review 38, no. 1 (April 2010): 48-56.

Bilson, James F. "Why the Youth Drift.” Methodist Times 3, no.1 (May-June 1989): 4.

Bittlinger, Arnold. "Charismatic Renewal: Opportunity for the Church?” Ecumenical Review 31, no. 3 (April 2003): 24751.

Boafo, P. K. John Wesley on the Road to Aldersgate: Early Influences that shaped his life and Theology. Accra: Methodist Book Depot, 2006.

Buttler, C. In the Light of the Council. London: Darton, Longman and Todd, 1968.

Carson, D.A. A Call to Spiritual Reformation. Michigan: Baker Book House, 1992.

Hollenweger, Walter J. From Azuza Street to the Toronto Phenomenon: Historical Roots of the Pentecostal Movement. Concilium, 1996.

Hill, M. E. The Church at Risk. Texas: Star Bible Publication, 1995.

Kudadjie, Joshua N. "The Relevance of the Methodist Prayer and Renewal Programme." A paper presented at the Accra District of the Methodist Church Ghana Consultation on Evangelism, January 28- 30, 1999.

Methodist Church Ghana. Resource Manual of Evangelism, Mission and Renewal Sub-division of the Methodist Church Ghana. Accra: Wesley Press, 2005.

Methodist Times 2, no. 5 (October 1988).

Methodist Times 3, no. 3 (Dec. 1989).

Methodist Times 4, no. 1 (January 1990).

Methodist Times 4, no. 2 (June 1990).

Methodist Times 4, no. 5 (December 1990).

Omenyo, Cephas Narh. Pentecost outside Pentecostalism: A Study of the Development of Charismatic Renewal in the Mainline Churches in Ghana. Netherlands: Boekencentrum Zoetermer, 2002.

Onyinah, Opoku. "Akan Witchcraft and the Concept of Exorcism in The Church of Pentecost." PhD Thesis, University of Birmingham, 2002.

Osei, Hosea. "Spiritual Renewal Programmes in Ghanaian Christianity: The Approach of the Methodist Church Ghana, Kumasi Diocese.” MA Diss., Christian Service University College, 2016.

"Report on Methodist Prayer Fellowship." Proceedings of 29th Annual Synod of Kumasi District of Methodist Church - Ghana, at Old Tafo, 17-21 May 1990, Representative Session. 142-3.

Schmidt, M. John Wesley: A Theological Biography. Epworth: London, 1962.

Stott, J. The Contemporary Christian: An Urgent Plea for Double Listening. Leicester: Inter-Varsity Press, 1993.

Tuttle Jr, R.G. John Wesley: His Life and Theology. Zondervan: Grand Rapids, 1978.

Tyson, E.D. "An Analysis of Neo-Pentecostal Mission Theology 1960-90: Four Case Studies." PhD Thesis, University of Edinburgh, 1993.

Warner, R. Prepare for Revival. London: Hodder and Stoughton, 1995.

Wesley News 1, no. 2 (January - March, 1990): 10-11

Wesley's Journal 1, 475-6.

Yalley, Doris E. "Ghanaian Methodist Spirituality in Relation with Neo-Pentecostalism." Ghana Journal of Religion and Theology 8, no. 1 (2018): 125-141. 